\title{
OVERCROWDED PRISONS IN PAKISTAN: UNDERSTANDING THE CRITICAL ROLE OF PROBATION, PAROLE OFFICERS AND COURTS
}

\author{
Mukhtyar Nabi \\ PhD Scholar, Department of Sociology, Quaid-i-Azam University, Islamabad \\ mukhtyar@soc.qau.edu.pk \\ Saddam Hussain \\ M.Phil. Scholar, Department of Economics, Federal Urdu University Islamabad \\ saddamuom75@gmail.com \\ Muhammad Kamran \\ PhD Scholar, Department of Anthropology, Quaid-i-Azam University, Islamabad \\ mkamran@anth.qau.edu.pk
}

\begin{abstract}
Prison is a place for rehabilitation of offenders in every country of the world. The present study has tried to explore the present-day situation of the prison system of Pakistan and discuss its overcrowding condition in all four provinces. There are total 120 prisons in the country which hold authorized space for not more than 57,712 prisoners, but the number of inmates is 77,275, which is far away from the authorized space. This congested prison system not only creates hurdles in rehabilitation of prisoners but makes them more criminal by mixing of low and high frequency offenders. It also leads to various health and behavioral problems. Rehabilitation is only possible if there is balance in authorized and available prisoners in the prisons. The present article has come up with some viable suggestion for concerned authorities that can better perform their duty in eradication of this problem. The authors discussed the role of parole and probation officers in the elimination of these numbers in prison. The majority of the prisoners in our prisons are under-trail, thus the role of the judiciary has also been explored in balancing the incarceration ratio in prisons.
\end{abstract}

Keywords: Prison System, Overcrowded Prisons, Parole and Probation, Judiciary, Courts, Pakistan.

\section{INTRODUCTION}

A prisoner is a person who commits an offence and gets proper and lawful punishment from the state's justice system to keep him/her in prison (Harigovind, 2013). Prison is a place where offenders are kept legally as a punishment for their wrong doing. It is also called a correctional place where offenders are held in confinement while either convicted or awaiting trial. It is normally surrounded by walls, fencing and other so many geographical features or barriers like security cameras, security lighting, electrified fencing, armed guarding towers, concertina wires, secured main gates, motion sensors, dogs and roving patrols for the purpose to prevent from escaping (Hanser, 2012; McShane \& Williams, 2004).

Imprisonment of convicted people is a universal phenomenon, and it is almost found in every society of the world (Walmsley, 2013; McLeod et al., 2020). According to the Global Prison Trends Report, at the start of 2020 about 11 million people were in incarceration, and among them the majority were under-trail. Prisons become overcrowded when the number of existing prisoners increased in prison than available space (Hough, Allen \& Solomon, 2008). In 2009, during the 8th commission on crime prevention and criminal justice, it was concluded that overcrowding in prisons has very serious effects on the health and behavior of the inmates living there and creates other security issues as well. The standard minimum rules for the treatment of prisoners (SMR) Rule 10 reads "prisoners shall provide all the accommodation facilities like sleeping place, health care, climate condition, minimum floor space, heating and ventilation and lighting" but in majority of the prisons around the world, the prisoners sleep in shifts or in congested place on one another with lack of basic facilities because of overcrowding.

Focusing on the prison system of Pakistan, one can find overcrowding in prisons, which is not a new phenomenon, and it is worst in comparison to the rest of the world. It has the 23rd largest 
prison population in the world while the 5th largest death row population (World Prison Brief, 2019). The number of prisoners in prisons is more than the available space. According to Malik (2019), the number of total prisons in Pakistan were 120 in all four provinces and the total capacity of accommodation was for 57,712 people, but states had accommodated 77,275 prisoners against the SMR rules and inmates were in the vilest physical and social condition (Dawn, 2019). According to the latest report of World Prison Brief in 2019, in Pakistani prisons 35.5 are legal offenders to whom legislation has announced imprisonment punishment while 64.5\% inmates are pre-trial or awaiting trial. Among them, $98.6 \%$ are male, $1.6 \%$ female, $1.7 \%$ juveniles, and $1.2 \%$ are those who held foreign citizenship (World Prison Brief, 2019).

Due to the overcrowded inmate population in Pakistani prisons, there are a lot of problems which have faced incarceration. Among them, the major issues are congestion in barracks, poor diet and health care management, unhygienic and poor sanitation, security and administrative issues (Khan, 2010). In order to make the environment of prison according to the SMR (standard minimum rules) friendly and friendly for the inmate, the state and other concerned organizations and institutions should work to decrease overcrowding in prisons and bring balance between the offenders and available space in prisons. In Pakistan the most important officials that can perform their fruitful role in bringing balance in different prisons of the country are parole and probation officers and judiciary or court system. But unfortunately, the number of parole and probation officers are really insufficient, and the judiciary is not in a position to make decisions in time for pre-trial or awaiting trial offenders.

\section{Objectives of the study}

1. To understand the present-day situation of the prison system of Pakistan.

2. To know about the role of parole and probation officers in balancing the prisoner ratio in prisons.

3. To examine the role of judiciary and courts in eliminations of prisoners' quantity in jails.

\section{PRISON SYSTEM OF PAKISTAN}

Pakistan is a Muslim majority country situated in South Asia with an estimated population of 220 million people according to the census of 2017 (Worldometers, 2020). Pakistan came into being in 1947, and its prisons system was in act even before the creation as British colonial legacy used this system as an instrument to overwhelm political opponents and nullify intimidations to crown rules (Khan, 2010). Although, the world turned into a post-modernized era, but the prison system of Pakistan is presenting the archaic state of affairs and following the stroppy and outmoded British old laws like "the prison Act of 1894", "Punjab Borstal Act 1926", and "Good conducted prisoners' probation release Act 1926" (Niazi, 2016).

After the independence in 1950, the first program for prison reform was introduced in Pakistan and the Ex-IG (UP combined India) Colonel Salamat Ullah was the chairman. Then after that, various committees were constituted for reforms in different provinces of the country under the support of the federal government, and these suggestions were unvaryingly agreed, but no prolific work was completed in the prison system due to financial constraints (Khan, 2010).

At present, 120 prisons exist in all the four provinces in Pakistan, and according to the 1973 constitution, these provinces are independent in their prison system. Khyber Pakhtunkhwa has 43 prisons, Punjab has 40 prisons, Sindh owns 26, and Baluchistan holds 11. These prisons are overcrowded because the total authorized capacity for 57,712 prisoners is available while in these prisons 77,275 prisoners are incarcerated (Malik, 2019). Although, the prison rule no. 745 showed that each prisoner should have 18 square meters in a barrack, but still these numbers are increasing day-by-day (Niazi, 2016).

\section{Types of Prisons}

They are of different types of prisons and among them the number of district jails is 51 , central jails are 25 and sub-jails are 21 . Beside this, the other types are consisted in low number as mentioned in table No.1. 
Table No. 1. Different Type of Prisons in Pakistan

\begin{tabular}{ccc}
\hline So. No. & Prison & No. of Prison \\
\hline 1 & High security Prison (H.S.P.) & 1 \\
2 & Central Jail (C.J.) & 25 \\
3 & District Jail (D.J.) & 51 \\
4 & Sub-Jail (S.J.) & 21 \\
5 & Judicial lock-up (J.L.) & 4 \\
6 & Bristol Institutions \&Juvenile jail (B.I) & 3 \\
7 & Youthful Offender industrial school (Y.I.) & 5 \\
8 & Women jail (W.J.) & 4 \\
9 & Open prison (O.P.) & 1 \\
10 & Interment center (I.C.) & 5 \\
& Total & 120 \\
\hline
\end{tabular}

Latest data (2020) from Prison Department of all four provinces

\section{Provincial Wise Distribution}

Among 120 prisons, 43 are present in Khyber Pakhtunkhwa, 40 are in Punjab, 26 in Sindh, and 11 are in Baluchistan.

Table No. 2. Provincial Wise Statistics of Prisons

\begin{tabular}{rlc}
\hline So. No. & Province & No. of Prison \\
\hline 1 & Khyber Pakhtunkhwa & 43 \\
2 & Punjab & 40 \\
3 & Sindh & 26 \\
4 & Baluchistan & 11 \\
& Total & 120 \\
\hline
\end{tabular}

Latest data (2020) from Prison Department of all four provinces

\section{Distribution on Type Basis}

The following table shows the distribution of prison in all the four provinces on the basis of their types.

Table No.3. Provincial wise distribution of different type of prisons

\begin{tabular}{lcccc}
\hline & \multicolumn{5}{c}{ Provinces } \\
\hline Prison types & Punjab & Sindh & Khyber Pakhtunkhwa & Baluchistan \\
\hline High security Prison & 01 & 00 & 00 & 00 \\
Central Jail & 09 & 06 & 06 & 04 \\
District Jail & 25 & 11 & 08 & 07 \\
Sub-Jail & 02 & 00 & 19 & 00 \\
Judicial lock-up & 00 & 00 & 04 & 00 \\
Bristol Institutions \&Juvenile jail & 02 & 00 & 01 & 00 \\
Youthful Offender industrial school & 00 & 05 & 00 & 00 \\
Women jail & 01 & 03 & 00 & 00 \\
Open prison & 00 & 01 & 00 & 00 \\
Interment center & 00 & 00 & 05 & 00 \\
Total & 40 & 26 & 43 & 11 \\
\hline
\end{tabular}

Latest data (2020) from Prison Department of all four provinces

\section{Prison Population}


The latest data from the prison departments of all provinces shows that the Pakistani jails have the authorized capacity to accommodate 57,712 prisoners, but there are 77,275 in numbers which made the system overcrowded in the country.

Table No. 4. Provincial Wise Statistics of Prison's Population

\begin{tabular}{clccc}
\hline So. No. & Province & No. of Prison & Authorized Capacity & Prison Population \\
\hline 1 & Punjab & 40 & 32,447 & 47,077 \\
2 & Sindh & 26 & 13,038 & 17,239 \\
3 & Khyber Pakhtunkhwa & 43 & 9,642 & 10,871 \\
4 & Baluchistan & 11 & 2,585 & 2,088 \\
& Total & 120 & 57712 & 77,275 \\
\hline
\end{tabular}

Latest data (2020) from Prison Department of all four provinces

\section{Convicted and Under-Trial Prisoners}

Although, the size of female inmates is less than male among all provinces, but the number of undertrial prisoners is more than the convicted ones, which is the reason for overcrowding in jails. Among the total 77,275 prisoners, only 29,367 are convicted, while the remaining 48008 are under-trial prisoners. Furthermore, there are also 1204 female prisoners in all prisons of the country.

Table No.5. Convicted and Udder-Trial Prisoners of both Genders

\begin{tabular}{llccccc}
\hline So. No & Province & $\begin{array}{c}\text { Prison } \\
\text { Population }\end{array}$ & Male & Female & Convicted & Under-trial \\
\hline 1 & Punjab & 47,077 & 45646 & 769 & 20352 & 26725 \\
2 & Sindh & 17,239 & 16852 & 214 & 4808 & 12431 \\
3 & Khyber & 10,871 & 10670 & 201 & 3203 & 7668 \\
& Pakhtunkhwa & & & & & \\
4 & Baluchistan & 2,088 & 2,068 & 20 & 904 & 1184 \\
Total & & 77,275 & 74870 & 1204 & 29267 & 48008 \\
\hline
\end{tabular}

Source: Malik (2019).

\section{The Role of Probation and Parole Officers}

Probation and parole are two early release systems for offenders, based on certain terms and conditions, which are considered fundamental to the criminal justice system of the country. The philosophy behind both systems is offender's community-based rehabilitation and reintegration to become a normal citizen of society. Furthermore, it claims that through punishment we cannot correct criminals and protect society (Tariq, 2019). In this regard, Bokil (1969) argued that "If the goal of the criminal justice system was to protect society, that goal is best achieved by a productive community correctional program". Similarly, Gullen and Gilbert (1982) states that in order to punish offenders, it is the responsibility of the state to care for their needs and insure their rehabilitation.

\section{Probation}

Probation is known as conditional release of an offender by court for a specific period under an imposed condition. This process is an alternative to incarceration, and the court holds the authority of offender's check and balance, modification of probation condition and even cancel the probation if the probationer deviates from the terms and condition of probation (Mackenzie, 2002). The purpose of probation is the early release of for the first time offender from sentence or the postponement of the final judgment of the case to give him/her an opportunity to improve their behavior in the community (Ahuja, 1979). This system of release can be traced from the judiciary system of the British and later in American courts, where offenders were released by judges on recognition or bail. Thus, these days release on recognition or bail is known as probation (Abidinsky, 2012).

In Pakistan, probation in the judiciary system was introduced during "The Probation of Offender Ordinance, 1960". In this ordnance, section 5 empowered the judiciary to release certain offenders on probation. It was clarified that it can be granted to those whose imprisonment is not more than three years. When the court releases an offender on probation, then it is the responsibility of the Reclamation and Probation Department (R\&P) in every province of the country to supervise and 
monitor their better rehabilitation in the community. From release to successful rehabilitation, parole and probation officer performs their due role (Bhutta, 2010).

In Pakistan, both high court, session court, judicial magistrate- 1st class, and any other empowered magistrate have the authority to release offenders on probation. In order to release the offender on probation, the authoritative bodies will be focused on the Social Investigation Report (SIR), that consisted of character, antecedents, commission and nature of the offence, home surrounding, and other circumstances (Bhutta, 2010).

Section 10 of the probation of offender ordinance 1960 claims that a probation officer shall be responsible for continuous investigation of the probationers. S/he is appointed under section 12 of the ordnance and is responsible to keep in touch and meet at least once a fortnight and evaluate his/her conduct to make sure that the probationer is obeying the terms and condition of conditional release. Similarly, on a regular basis the probationer officer will be aware of court regarding the living condition of a probationer in the community. Further, probation can be availed by all male and female offenders whose offense is not punishable with death which are mentioned in Pakistan Penal Code chapter VI \& VII under section 216A (Probation of Offenders' Ordinance, 1960).

\section{Parole}

Parole is the process where offenders are early released for their good conducts in prison and have completed the mandatory period mentioned under "Good Conduct Prisoner's Probational Release Act 1926, Rules 1972 (Pakistan) (Bhutta, 2010). The origin of the parole system can be traced from the end of the 19th century in England. Prior to the mid of the 19th century, mostly the prisoners were sentenced to a flat or kept in prison. The imprisonment time of prisoners was based on their offence nature, and every specific crime was its own time of incarceration. This long-term imprisonment created the problem of overcrowding in prisons; thus, mass pardons and prison wardens were notified to randomly release the old prisoners and make space for the new one. At that time, an Englishman,"Captain Alexander Maconochie", and an Irishman, "Sir Walter Crofton", developed an early parole system (MacKenzie, 2002).

The major difference between probation and parole is that, in probation, the court has the power to release the offender, while in the parole system, the Executive (Home Secretary) has the power to release certain eligible offenders on parole (Bhutta, 2010). Nowadays, the system of parole is almost in every society of the world, and the major aim of this system is to remove good antecedent offenders among the criminal environment of jail and give them a chance to live a a productive life in society. This system is functional in Pakistan up to some extent and parole officers of the reclamation $\&$ probation department supervise parolees on an incessant basis in order to keep them good citizens of the country.

\section{Probation and Parole Statistics}

At the present, in Pakistan, the data about probation and parole is varying among different sources such as newspapers and scientific articles, and there is no specific authentic source from where the statistics regarding this system can be obtained. Arshad Mahmud in his report published by Niazi (2016) in a daily newspaper discussed the parole in the probation system in Punjab. According to him, the reclamation and probation department of Punjab consisted of 95 officers and by excluding directors, deputy directors and assistant directors, we only remained 55 male probation officers and 2 females, while 15 male parole officers and 5 females. Furthermore, for these 55 male and 2 female probation officers, the total number of probationers are 23,395 and for the 15 male and 5 parole officers, the number of parolees is 576. The statistics show a huge difference and seem to put a big burden on the shoulders of respective officers.

If we move 10 years back for authentic data regarding this system in all four provinces of the country, the National Academy for Prison Administration (2010) provides clear statistics (shown in Table No. 6). The table elucidates less number of parole and probation officers in all provinces and the huge number of probationers and parolees. In both statistics, the number shows that for a single officer there are about 500 or above probationers or parolees. 
Table No. 6 Provincial wise situation of probation and parole in Pakistan

\begin{tabular}{|c|c|c|c|c|c|c|c|c|c|c|c|c|c|c|c|c|}
\hline \multirow{3}{*}{$\begin{array}{c}\text { Provinc } \\
\mathrm{e}\end{array}$} & \multicolumn{3}{|c|}{$\begin{array}{c}\text { Probation } \\
\text { Officers }\end{array}$} & \multicolumn{3}{|c|}{ Parole Officers } & \multicolumn{5}{|c|}{ Probationers } & \multicolumn{5}{|c|}{ Parolees } \\
\hline & $\mathrm{Ma}$ & fem & tot & $\mathrm{Ma}$ & Fem & To & Mal & Fem & & enile & tota & $\mathrm{Ma}$ & Fem & & enile & To \\
\hline & & ale & al & le & ale & tal & e & ale & $\begin{array}{c}\text { Ma } \\
\text { le }\end{array}$ & $\begin{array}{c}\text { Fem } \\
\text { ale }\end{array}$ & 1 & le & ale & $\begin{array}{c}\mathrm{Ma} \\
\mathrm{le}\end{array}$ & $\begin{array}{c}\text { Fem } \\
\text { ale }\end{array}$ & tal \\
\hline Punjab & 35 & 1 & 36 & 8 & 2 & 10 & $\begin{array}{r}207 \\
74\end{array}$ & 225 & $\begin{array}{c}21 \\
7\end{array}$ & 0 & $\begin{array}{c}212 \\
16\end{array}$ & 0 & 0 & 0 & 0 & 99 \\
\hline $\begin{array}{l}\text { Khyber } \\
\text { Pakhtun }\end{array}$ & 16 & 6 & 22 & 2 & 0 & 2 & $\begin{array}{c}160 \\
7\end{array}$ & 17 & 43 & 2 & $\begin{array}{c}166 \\
9\end{array}$ & 0 & 0 & 0 & 0 & 5 \\
\hline $\begin{array}{l}\text { Knwa } \\
\text { Sindh }\end{array}$ & 1 & 0 & 1 & 1 & 0 & 1 & 277 & 0 & 33 & 0 & 310 & 0 & 0 & 0 & 0 & 7 \\
\hline $\begin{array}{l}\text { Baluchis } \\
\quad \tan \end{array}$ & 6 & 0 & 6 & 2 & 2 & 4 & 2 & 0 & 0 & 0 & 2 & 0 & 0 & 0 & 0 & 80 \\
\hline Pakistan & 58 & 7 & 65 & 13 & 4 & 17 & $\begin{array}{c}226 \\
60\end{array}$ & 242 & $\begin{array}{c}29 \\
3\end{array}$ & 2 & $\begin{array}{c}231 \\
97\end{array}$ & 0 & 0 & 0 & 0 & $\begin{array}{c}19 \\
1\end{array}$ \\
\hline
\end{tabular}

Dated 30 March, 2010, National Academy for Prison Administration (NAPA) Lahore Pakistan (former CJSTI)

The Role of Judiciary

Among all justice systems of the world, the court occupied the major position. When an offender commits an offence and police arrest him/her, so the court comes in act after prosecution in the criminal justice system. Here the prosecutor presents all the evidences against the offender for his/her offence and in defense the offender also gives his/her own evidence. Then the court concludes the case either to give punishment to the offender or to release him/her (Barakatullah, 2010). The judiciary of Pakistan consists of three levels, the federal courts, lower division courts (district courts, session courts, and courts of magistrate) and the supreme judicial council. Among the all judiciary system, lover division courts are considered the most important section of the criminal justice system. The sequence of courts can be better understood from the following diagram:

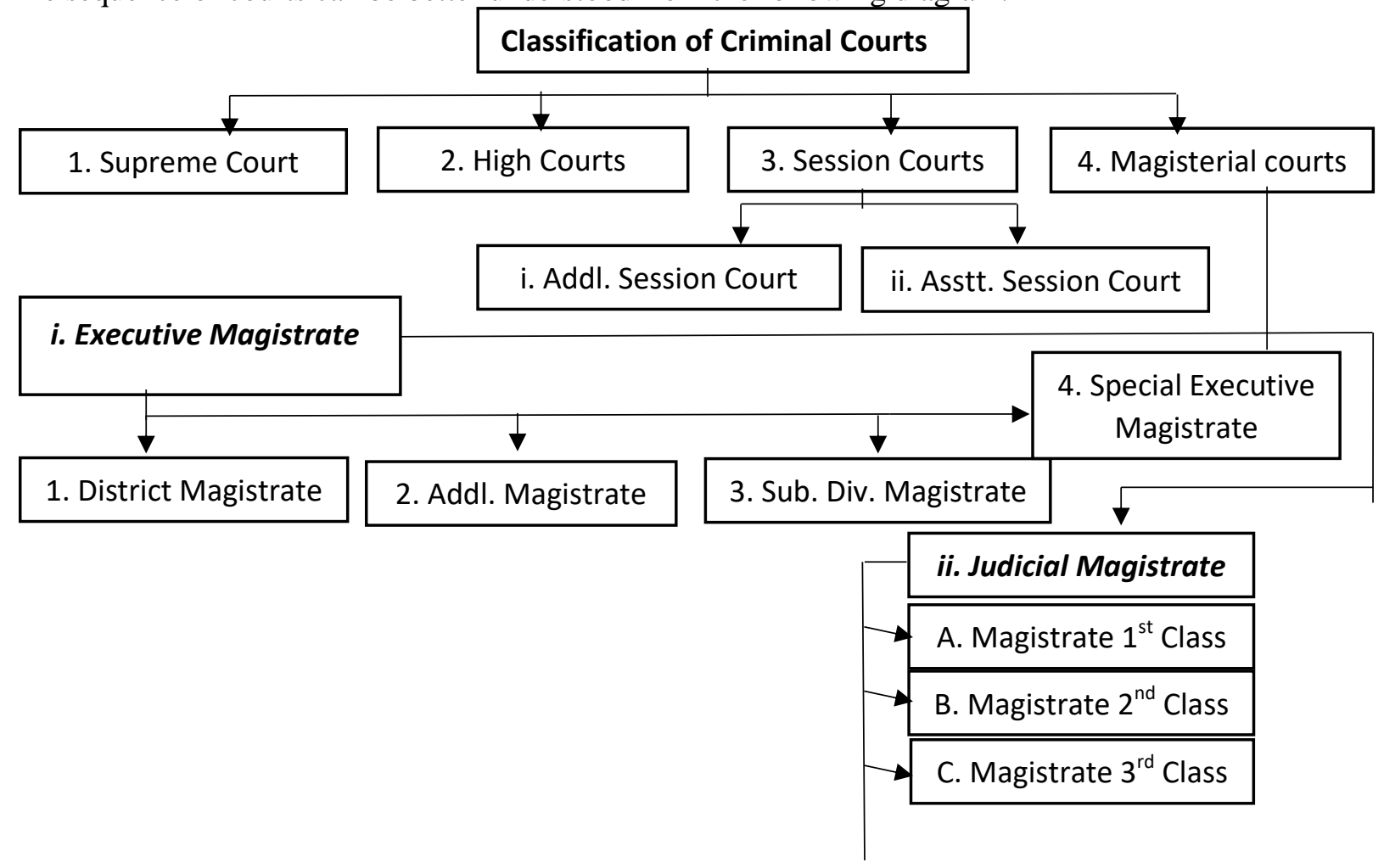


Fig. 1. Classification of Courts in Pakistan, Source: Barakatullah (2010)

The above courts are present in all provinces of the country, but astonishingly, they are unable to reduce overcrowding in the country's prisons. It was noted that at the start of 2014, by excluding cases of special courts and administrative tribunals, 138,296 cases were pending in the superior courts (Supreme Court, High Courts) and above 2.6 million cases in the subordinate judiciary. The police, judges and lawyers argued that it is due to less number of courts, and in order to mitigate these cases, the government should double the number of courts (Naz et al., 2014). By increasing the number of courts, the problem is not only the problem, but less concentration on people's problems and by delaying their cases instead of concluding them in time is the big issue of the judiciary system.

\section{CRITICAL DISCUSSION}

Islam tells us that we should hate the crime, not the criminal, and this is also the philosophy of the modern prison system. Here the focus is upon the rehabilitation of the offender instead of torturing and keeping him/her nonproductive in incarceration. In this regard, Pakistan has total 120 prisons in all the provinces and work on the philosophy to rehabilitate the offender. Offenders can only be rehabilitated if they are provided with a smooth environment according to the SMR. But unfortunately, here in this country the jails are congested and the number of authorized spaces is 57,712 while they have incarcerated 77,275 prisoners which not only have created social, behavioral and health issues but at the same time have had the worst effects on the national economy. The basic reason for this overcrowding is under-trial prisoners because among the total 77,275 inmates, only 29,267 are actually convicted while the remaining are under-trial. In order to reduce this overcrowding in prisons, the state can use the reclamation and probation department and the justice system. The main figures of the reclamation and probation department that can reduce this increasing number are parole and probation officers, but the number of these officers is very lesser in all the provinces, and they are unable to bear the huge burden of probationers and parolees.

According to the statistics of the National Academy for Poisons Administration, a single probation and parole officer is for round about 700 to 1000 probationers and parolees, which makes them unable to complete check-and-balance. If the government increases the number of these officers in all provinces, then the phenomenon of overcrowding can be controlled and the system of parole and probation be considered a constructive tool (Fayyazuddin, Jillani, \& Jillani, 1997). Besides, the judiciary system can also play a key role because $64 \%$ of the inmates are under-trial, and if the judiciary performs their work properly, then, the number of incarcerations in prisons can reduce. Unfortunately, in the superior courts of Pakistan about 138,296 cases are pending and the number of pending cases in subordinate courts are around 2.6 million. In crux, we can say that in order to reduce overcrowding in prisons and control on various issues faced by prisoners, the states should strengthen the judiciary and parole and probation system. By reducing inmate number in prisons, it is not only a beneficiary for the prison environment but will also have a positive impact on the national economy as well.

\section{CONCLUSION}

Prison is a place where offenders are kept after committing an offence. In modern time the philosophy of prisons has focused on the rehabilitation of criminals, but when it becomes overcrowded, then it negatively affects the inmates' life. This study concluded that in Pakistan, total 120 prisons exist in all four provinces, and they are extensively overcrowded. The number of incarcerated is doubled than the authorized capacity. This overcrowding is basically in violation of Standard Minimum Rules (SMR), but they still kept much of the prisoners in a single barrack. Among the total incarceration, about 64 percent of prisoners are under-trial, which is considered a huge amount, and courts have failed to conclude their cases. This overcrowding not only has an effect on the rehabilitation of the inmate but also on the burden on the national economy as well. In order to bring balance among prisons and mitigate its overcrowding, there are three important officials in the country, the parole and probation officers and the courts. These officials can perform the best role in criminal justice system, but unfortunately, in Pakistan the number of these officers is very less, and with this limited parole and probation officers they are unable to serve the huge number of probationers and parolees. It is also noted that the number of courts is less in the country for solving thousands of cases, but it is also the 
fact that they take a lot of time to conclude even a single case. The overcrowding of prisons can only be controlled if the state hires more parole and probation officers in each province according to the needs of inmates, and the courts should work swiftly to conclude cases within two to three meetings. 


\section{REFERENCES}

Abaninsky, H. (2012). Probation and parole theory and practice. London: Pearson.

Ahuja, R. (1979). Probation act-A sociological appraisal. The Indian Journal of Social Work, XL(2), 201208.

Barakatullah. (2010). Judicial system of Pakistan. Pakistan Journal of Criminology, 2(3), 15-34.

Bhutta, M.H. (2010). Community based rehabilitation of offenders: An overview of probation and parole system in Pakistan. Pakistan Journal of Criminology, 2(3), 51-67.

Bokil, M.K. (1969). Probation offenders act, 1958. Samaj Seva.

Dawn (2019, Nov. 12). Overcrowded Jails. https://www.dawn.com/news/1516217

Fayyazuddin, S., Jillani, A., \& Jillani, Z. (1998). The State of Pakistan's Children, 1997. Delhi: APH Publishing Corporation.

Gullen F. \& Gilbert, K. (1982). Reaffirming rehabilitation. Cincinnati, OH: Anderson.

Hanser, R.D. (2012). Introduction to corrections. Sage Publications.

Harigovind, P.C. (2013). The Indian Jurisprudence on Prison Administration and the Legislative Concerns. IOSR Journal of Humanities and Social Science, 9(5), 24-29.

Hough, M., Allen, R. \& Solomon, E. (Eds.). (2008). Tackling prison overcrowding: build more prisons? Sentence fewer offenders? Policy Press.

Khan, M.M. (2010). The prison system of Pakistan. Pakistan Journal of Criminology, 2(3), 35-50.

MacKenzie, D. L. (2002). Probation and parole: History, goals, and decision-making. In Encyclopedia of Crime and Justice (Ed J Dressier). New York, MacMillan. Retrieved from https://www.encyclopedia.com/law/legal-and-political-magazines/probation-and-parolehistory-goals-and-decision-making

Mahmood, A. (2016, Feb. 9). The neglected probation system. Express Tribune. https://tribune.com.pk/story/1043366/the-neglected-probation-system

Malik, H. (2019, Nov. 6). Under-trial prisoners outnumber convicts in jails across Pakistan. The Express Tribune. https://tribune.com.pk/story/2094531/1-trial-prisoners-outnumber-convicts-jails-acrosspakistan/

McLeod, K.E., Butler, A., Young, J.T., Southalan, L., Borschmann, R., Sturup-Toft, S., \& Martin, R. E. (2020). Global prison health care governance and health equity: A critical lack of evidence. American Journal of Public Health, 110(3), 303-308.

McShane, M.D., \& Williams, F.P. (Eds.) (2004). Encyclopedia of American prisons. Routledge.

National Academy for Prisons Administration. (2010). Province-wise authorized capacity, prison staff strength and prison population as on 30-06-2010. Lahore: Ministry of Interior, Government of Pakistan. Retrieved from http://pscriminology.com/wpcontent/uploads/2018/01/PrisonStatisticsinPakistanfor2010.pdf

Naz, A., Saeed, G., Ahmad, W., Bangash, S., \& Khan, N. (2014). The emergence of the rule of law and policing in Pakistan: A historical overview. Journal of Law and Society, 45(65), 127-140.

Niazi, A.S.K. (2016, Dec. 19). Prisons in Pakistan. Pakistan Today. https://www.pakistantoday.com.pk/2016/12/18/prisons-in-pakistan/

Prison Department Khyber Pakhtunkhwa. (2020). http://www.prisons.kp.gov.pk/

Prison Department Punjab. (2020). www.prisons.punjab.gov.pk.

Probation of Offenders' Ordinance. (1960). Ordinance No. XLV. https://kpcode.kp.gov.pk/uploads/West Pakistan_Probation_of_Offenders_Rules 1961.pdf.

Sindh Prisons Department. (2020). www.sindh.gov.pk

Tariq, A. (2019). Rights of prisoners: A comparative study of Shariah \& law with special reference to Pakistani statutes and case law (Unpublished doctoral dissertation) International Islamic University, Islamabad.

UNODC. (2009). Commission on Crime Prevention and Criminal Justice Commission on Crime Prevention and Criminal Justice Eighteenth Session (16 - 24 April 2009). Vienna, Austria: United Nation's Office on Drugs and Crime. Retrieved from https://www.unodc.org/unodc/en/commissions/CCPCJ/session/18_Session_2009/CCPCJ_18.ht $\underline{\mathrm{ml}}$

Walmsley, R. (2013). World prison population list. International Centre for Prison Studies.

World Prison Brief. (2019) Highest to Lowest - Prison Population Total. Retrieved from www.prisonstudies.org

Worldometers. (2020). Pakistan population. Retrieved from https://www.worldometers.info/worldpopulation/pakistan-population/ 